\title{
A revaluation of rhipidocystid echinoderms based on a new flattened blastozoan from the Upper Ordovician of Maryland, USA
}

Samuel Zamora, James Sprinkle, and Colin D. Sumrall

Acta Palaeontologica Polonica 65 (3), 2020: 455-465 doi:https://doi.org/10.4202/app.00718.2019

A new rhipidocystid echinoderm from the Upper Ordovician Chambersburg Formation in western Maryland (USA) is here described based on four exquisitely preserved specimens. Specimens of Durhamicystis americana gen. et sp. nov. preserve both thecal sides and the oral area, with identification of major apertures including peristome, periproct, gonopore, and hydropore. This allows orientation of this species and proper comparison across all rhipidocystids. Durhamicystis americana has a large theca composed of ten marginal plates with only two basals on the posterior side, two ambulacra and seven large oral plates with brachioles attached either on orals or smaller flooring plates. Rhipidocystids include taxa with lateral flattening along the BC-DE axis (i.e., Rhipidocystis) and others along the anterior-posterior A-CD axis (i.e., Durhamicystis, Neorhipidocystis, and Petalocystites) suggesting rhipidocystids may be paraphyletic.

Key words: Echinodermata, Blastozoa, Rhipidocystidae, Paleozoic, Chambersburg Formation, North America.

Samuel Zamora [s.zamora@igme.es], Instituto Geológico y Minero de España (IGME), C/Manuel Lasala, 44, 9³, 50006, Zaragoza, Spain and Grupo

Aragosaurus-IUCA, Área de Paleontología, Facultad de Ciencias, Universidad de Zaragoza, Zaragoza, Spain. James Sprinkle [echino@jsg.utexas.edu], Department of Geological Sciences, Jackson School of Geosciences, University of Texas, 1 University Station C1100, Austin TX, 78712-0254, USA. Colin D. Sumrall [csumrall@utk.edu], Department of Earth and Planetary Sciences, University of Tennessee, Knoxville, TN 37996-1410, USA.

This is an open-access article distributed under the terms of the Creative Commons Attribution License (for details please see creativecommons.org), which permits unrestricted use, distribution, and reproduction in any medium, provided the original author and source are credited. 
Forif Full text $(34,574.2 \mathrm{kB})$ 